\title{
EARTHQUAKE RESPONSE PREDICTION OF REINFORCED CONCRETE BUILDINGS
}

\author{
By Dr. Masakazu OZAKI, Dr. Makoto WATABE, \\ Masaya HIROSAWA, Dr. Yutaka MATSUSHIMA, \\ and Yutaka YAMAZAKI*, Members of A.I.J.
}

\section{SYNOPSIS}

This paper is an application of the random vibration theory in earthquake engineering, from which a general analytical method is developed for the response of a multi-story building with a linear stable system subjected to earthquake excitation.

This analytical method is applied to evaluate the response of a three story building subjected to an accelerometer recording of the Tokachi-Oki earthquake. Expected maximum story displacements and expected number of cycles with varying intensities of the repeated story shearing forces due to the strong ground motion are computed and compared with the corresponding values obtained by a deterministic analysis method.

Hence, a dynamic response prediction method for the expected intensity of future earthquakes is here by discussed.

\section{INTRODUCTION}

The Tokachi-Oki earthquake which occurred in the northern part of Japan on 16 th, May, 1968 caused extensive damages to the columns of some reinforced concrete buildings.

Numerous investigations as well as inspections on this area have been carried out to determine the process to the damage in certain type of buildings.

This paper deals with an application of random vibration theory in earthquake engineering.

It is not always possible to fully define the excitation of a particular dynamic system, however, in such case it may be possible to characterize the excitation in a probabilistic manner which then makes it possible to predict with any degree of accuracy the future dynamic response of buildings withstanding strong motion earthquake excitation by probabilistic methods. This method differs from deterministic methods and the dynamic response predictions are made in a probabilistic sense only.

Chart 1 Transmissible mechanism

An idealized model based on investigations on damaged reinforced concrete buildings is shown in Fig. 1. The transmissible mechanism of general earthquake excitation considered is shown in Chart 1.

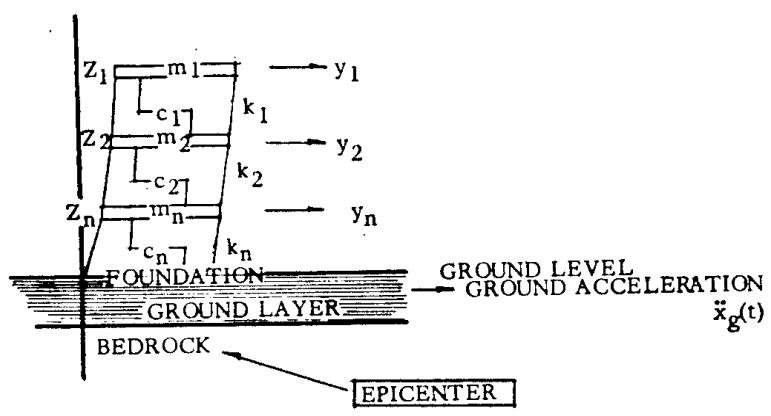

Fig. 1 Idealized Model of Building

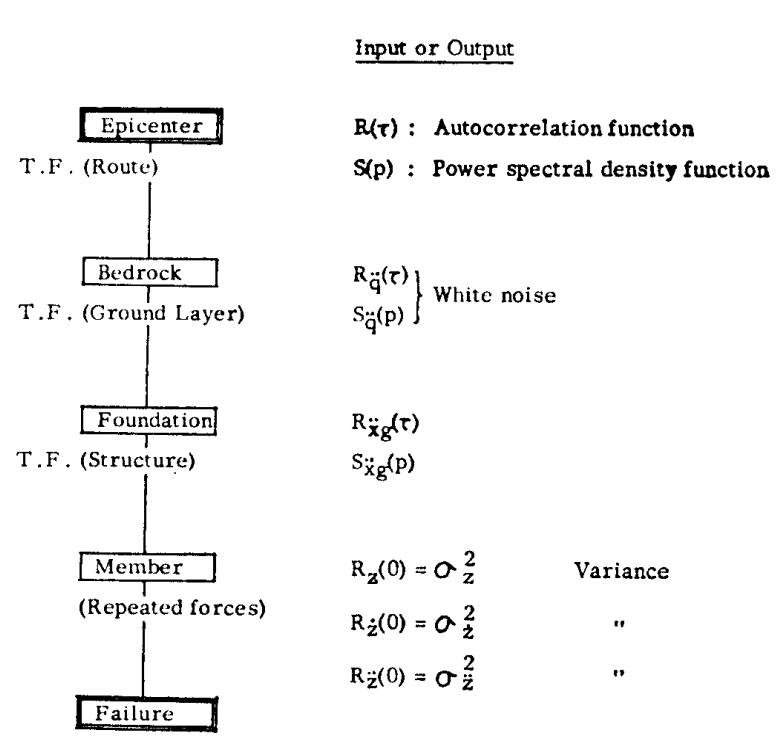

* Research Member of Building Research Institute, Ministry of Construction 


\section{VIBRATION OF GROUND SURFACE}

It has been suggested by Dr. Kanai and Dr. Tajimi that the autocorrelation and the power spectral density functions of the ground accelerations of many past earthquake motions are approximated by the following equations

$$
\begin{aligned}
& R_{\ddot{x} \boldsymbol{g}}(\tau)=\pi(t) S_{0}\left\{\left(2 \xi+\frac{1}{2 \xi}\right) e^{-\xi \omega_{g} \tau} \cdot \cos \omega_{d} \tau+\frac{\xi}{\sqrt{1-\xi^{2}}}\left(\frac{1}{2 \xi}-2 \xi\right) e^{-\xi \omega_{g} \tau} \cdot \sin \omega_{d q} \tau\right\} \\
& S_{\ddot{x}_{\theta}}(p)=\frac{1+4 \xi^{2}\left(\frac{p}{\omega_{g}}\right)^{2}}{\left[1+\left(4 \xi^{2}-2\right)\left(\frac{p}{\omega_{g}}\right)^{2}+\left(\frac{p}{\omega_{g}}\right)^{4}\right]} S_{0}
\end{aligned}
$$

where $\xi$ and $\omega_{g}$ may be thought of as ground damping factor and predominant frequency, respectively, and where $S_{0}$ is a constant power spectral density function (see Fig. 2).

This idea has been presented as a result of analyses of many past earthquake motion considering that the spectrum observed at bedrock is characterized by a constant pattern, while the spectrum at the ground surface is multiplied by the vibration property of the ground layer.

The plot of Eq. (2) shows that the function has one high peak at $p=\omega_{g}$ as shown in Fig. 3(b).

However, the power spectral density functions observed at ground surface happen to show more than one distinguished peak.

In such case, the autocorrelation and the power spectral density functions may be expressed as the sum of each function.

$$
\begin{aligned}
& R_{x_{g}(\tau)}=\sum_{j=1}^{n} \pi \omega_{g j} S_{j}\left\{\left(2 \xi_{j}+\frac{1}{2 \xi_{j}}\right) e^{-\xi j \omega_{g} \tau \tau} \cdot \cos \omega_{d q j} \tau+\frac{\xi_{j}}{\sqrt{1-\xi_{j}^{2}}}\left(\frac{1}{2 \xi_{j}}-2 \xi_{j}\right) e^{-\xi j \omega_{g} j \tau} \cdot \sin \omega_{d g j} \tau\right. \\
& S_{\ddot{x} g}(p)=\sum_{j=1}^{n} \frac{1+4 \xi_{j}{ }^{2}\left(\frac{p}{\omega_{g j}}\right)^{2}}{\left[1+\left(4 \xi_{j}^{2}-2\right)\left(\frac{p}{\omega_{g j}}\right)^{2}+\left(\frac{p}{\omega_{g j}}\right)^{4}\right]} S_{j}
\end{aligned}
$$
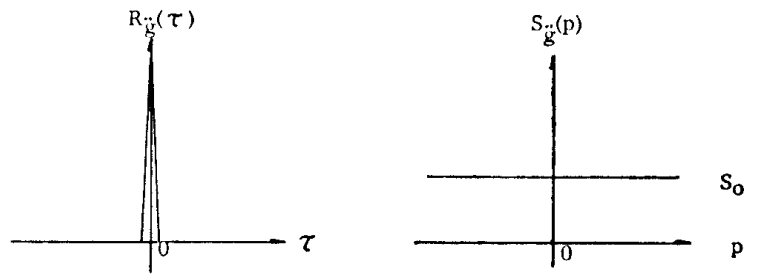

(a) (b)

Fig. 2 Auto-Correlation and Power Spectral Density Functions of White Noise

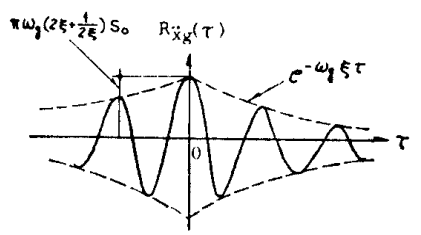

(a)

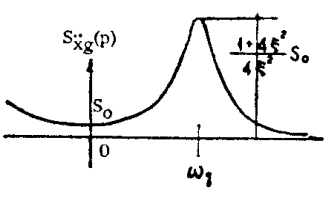

Fig. 3 Auto-Correlation and Power Spectral Density Function of Ground Acceleration

Therefore, the variance of the ground acceleration $\ddot{x}_{\theta}$ with respect to time $t$ is simply obtained according to the property of the autocorrelation function, i.e.,

$$
\sigma_{\ddot{x}_{g}}{ }^{2}=R_{\ddot{x}_{\theta}}(0)=\pi \omega_{g} S_{0}\left(2 \xi+\frac{1}{2 \xi}\right)
$$

or

$$
R_{\ddot{x}_{g}}(0)=\sum_{j=1}^{n} \pi \omega_{o j} S_{j}\left(2 \xi_{j}+\frac{1}{2 \xi_{j}}\right)
$$




\section{VIBRATION OF MULTI-DEGREE OF FREEDOM SYSTEMS}

The foundations of buildings are supposed to be subjected to the above mentioned ground acceleration $\ddot{x}_{q}(t)$ in the lateral direction as shown in Fig. 1, where $y_{i}(i=1,2, \cdots, m)$ denoted the absolute displacements of the floors.

The ground displacement is denoted by $x_{q}$.

Consequently, the floor displacements relative to the foundation are given by $\left(y_{i}-x_{g}\right)(i=1,2, \cdots$, $m$ ).

$$
\left[{ }^{\prime} m\right]\{\ddot{y}\}+[c]\left\{\dot{y}-\dot{x}_{g}\right\}+[k]\left\{y-x_{g}\right\}=0
$$

Introducting anew variable

$$
z_{i}=y_{i}-x_{g}
$$

the equations of motion become

$$
[\backslash m]\{\ddot{z}\}+[c]\{\dot{z}\}+[k]\{z\}=-[\backslash m]\left\{\ddot{x}_{g}\right\}
$$

since $\left[{ }^{\prime} m\right]$ is a diagonal matrix and

$$
\left\{\ddot{x}_{g}\right\}=\ddot{x}_{g}\left\{\begin{array}{c}
1 \\
\vdots \\
\vdots
\end{array}\right\}
$$

the right-hand side of Eq. (7) can be written as

$-\ddot{x}\{m\}$

where $\{m\}$ is a column matrix containing the masses $m_{1}, m_{2}, \cdots, m_{n}$. Eq. (7) then becomes

$\left[m_{\backslash}\right]\{\ddot{z}\}+[c]\{\dot{z}\}+[k]\{z\}=-\ddot{x}_{g}\{m\}$

The relative floor displacements $z_{i}$ are expressed in terms of the normal modes $\Phi$ and normal coordinates $\eta_{r}(r=1,2, \cdots, m)$, where

$$
z_{i}(t)=\Sigma \Phi_{i r} \eta_{r}(t)
$$

or

$$
\{z\}=[\Phi]\{\eta\},\{\dot{z}\}=[\Phi]\{\dot{\eta}\} \text { and }\{\ddot{z}\}=[\Phi]\{\ddot{\eta}\}
$$

Substituting Eq. (9) into Eq. (8) and premultiplying the resulting equation by $[\Phi]^{T}$, a set of decoupled differential equations in the normal coordinates $\eta_{r}$ is obtained as follows;

$$
\left[M_{r}\right]\{\ddot{\eta}\}+2 \xi\left[M_{r}\right]\{\dot{\eta}\}+\left[\omega_{r}{ }^{2}\right]\left[M_{r}\right]\{\eta\}=-\ddot{x}_{g}[\Phi]^{T}\{m\}
$$

where

$$
\begin{aligned}
& {\left[M_{r}\right]=[\Phi]^{T}[\backslash m][\Phi]} \\
& 2 \zeta\left[\backslash M_{r}\right]=[\Phi]^{T}[c][\Phi] \\
& {\left[\omega_{r}{ }^{2}\right]\left[M _ { r } \left[=[\Phi]^{T}[k][\Phi]\right.\right.}
\end{aligned}
$$

The $r$-th row of Eq. (10) has the form

$$
\ddot{\eta}_{r}+2 \zeta \dot{\eta}_{r}+\omega_{r}^{2} \eta_{r}=\frac{\Gamma_{r}}{M_{r}} \ddot{x}_{\theta}
$$

in which $\Gamma_{r}=\left\{\Phi^{(r)}\right\}^{T}\{m\}$

The solution of Eq. (11) is given by

$$
\eta_{r}=-\frac{\Gamma_{r}}{\omega_{d r} M_{r}} \int_{-\infty}^{t} \ddot{x}_{\partial} e^{-\zeta \omega r(t-\tau)} \sin \omega_{d r}(t-\tau) d \tau
$$

where $\zeta, \omega_{r}$ and $\omega_{d r}$ denote the structural damping ratio $(\zeta=0.05)$, the undamped natural frequency and the damped frequency in the under critically damped case, respectively.

The autocorrelations of $\eta_{r}$ and $\dot{\eta}_{r}$ can be expressed as follows;

$$
\begin{aligned}
& R_{\eta_{r}}(\tau)=E\left[\eta_{r}(t) \eta_{r}(t+\tau)\right] \\
& =\frac{\Gamma_{r}^{2}}{\omega_{r}{ }^{4} M_{r}^{2}} \int_{-\infty}^{\infty} \frac{S_{\ddot{x}_{g}}(p) \cdot e^{i p \tau}}{\left[1+2 i \zeta\left(\frac{p}{\omega_{r}}\right)-\left(\frac{p}{\omega_{r}}\right)^{2}\right]\left[1-2 i \zeta\left(\frac{p}{\omega_{r}}\right)-\left(\frac{p}{\omega_{r}}\right)^{2}\right]} d p \\
& R \dot{\eta}_{r}(\tau)=E\left[\dot{\eta}_{r}(t) \dot{\eta}(t+\tau)\right]=-R^{\prime \prime} \eta_{r}(\tau) \\
& =\frac{\Gamma_{r}^{2}}{\omega_{r}{ }^{4} M_{r}^{2}} \int_{-\infty}^{\infty} \frac{S_{\ddot{x}_{g}}(p) p^{2} e^{i p \tau}}{\left[1+2 i \zeta\left(\frac{p}{\omega_{r}}\right)-\left(\frac{p}{\omega_{r}}\right)^{2}\right]\left[1-2 i \zeta\left(\frac{p}{\omega_{r}}\right)-\left(\frac{p}{\omega_{r}}\right)^{2}\right]} d p
\end{aligned}
$$


Therefore, the mean squares of the responses

$\overline{z_{i}{ }^{2}(x, t)}$ and $\overline{\dot{z}_{i}{ }^{2}(x, t)}$ become

$$
\begin{aligned}
& \overline{z_{i}{ }^{2}(x, t)}=R_{z_{i}}(0)=\sum_{r=1}^{m} \Phi_{i r}{ }^{2}(x) \frac{\Gamma_{r}{ }^{2}}{\omega_{r} M_{r}{ }^{2}} \int_{-\infty}^{\infty}\left|H\left(\omega_{r} p\right)\right|_{2} S_{\ddot{x} g}(p) d p \\
& \overline{\dot{z}_{i}{ }^{2}(x, t)}=R_{\dot{z}_{i}}(0)=\sum_{r=1}^{m} \Phi_{i r}{ }^{2}(x) \frac{\Gamma_{r}{ }^{2}}{\omega_{r}^{4} M_{r}{ }^{2}} \int_{-\infty}^{\infty}\left|H\left(\omega_{r} p\right)\right|^{2} p^{2} S_{\ddot{x} g}(p) d p
\end{aligned}
$$

where $i=1,2, \cdots, m$ represents the levels of the building in Fig. 1 and

$$
\begin{aligned}
& \left|H\left(\omega_{r} p\right)\right|^{2}=\frac{1}{\left[1+2 i \zeta\left(\frac{p}{\omega_{r}}\right)-\left(\frac{p}{\omega_{r}}\right)^{2}\right]\left[1-2 i \zeta\left(\frac{p}{\omega_{r}}\right)-\left(\frac{p}{\omega_{r}}\right)^{2}\right]} \cdots \cdots \\
& S_{\ddot{x}_{g}}(p)=\sum_{j=1}^{n} \frac{\left[1+2 i \xi_{j}\left(\frac{p}{\omega_{g j}}\right)\right]\left[1-2 i \xi_{j}\left(\frac{p}{\omega_{g j}}\right)\right]}{\left[1+2 i \xi_{j}\left(\frac{p}{\omega_{g j}}\right)-\left(\frac{p}{\omega_{g j}}\right)^{2}\right]\left[1-2 i \xi_{j}\left(\frac{p}{\omega_{g j}}\right)-\left(\frac{p}{\omega_{g j}}\right)^{2}\right]} S_{j}
\end{aligned}
$$

Substituting the above equations into Eqs. (15) and (16) the mean square values are written in the following equivalent forms, i.e.,

$$
\begin{aligned}
\overline{z_{i}^{2}(x, t)} & =\sum_{j=1}^{n} \sum_{r=1}^{m} \Phi_{i r}{ }^{2}(x) \frac{\Gamma_{r}{ }^{2} S_{j}}{\omega_{r}{ }^{4} M_{r}{ }^{2}} \int_{-\infty}^{\infty}\left|\frac{i B p+1}{1+i A_{1} p-A_{2} p^{2}-i A_{3} p^{3}+A_{4} p^{4}}\right|^{2} d p \\
\overline{\dot{z}_{i}{ }^{2}(x, t)} & =\sum_{j=1}^{n} \sum_{r=1}^{m} \Phi_{i r}{ }^{2}(x) \frac{\Gamma_{r}{ }^{2} S_{j}}{\omega_{r}{ }^{4} M_{r}^{2}} \int_{-\infty}^{\infty}\left|\frac{-B p^{2}+i p}{1+i A_{1} p-A_{2} p^{2}-i A_{3} p^{3}+A_{4} p^{4}}\right|^{2} d p
\end{aligned}
$$

in which

$$
\begin{aligned}
& A_{1}=2\left(\frac{\xi_{j}}{\omega_{g j}}+\frac{\zeta}{\omega_{r}}\right) \\
& A_{2}=\frac{1}{\omega_{g i}{ }^{2}}+4 \xi \xi_{j} \zeta \frac{1}{\omega_{g j} \omega_{r}}+\frac{1}{\omega_{r}^{2}} \\
& A_{3}=2\left(\frac{\xi_{j}}{\omega_{g j} \omega_{r}{ }^{2}}+\frac{\zeta}{\omega_{g j}{ }^{2} \omega_{r}}\right) \\
& A_{4}=\frac{1}{\omega_{g j^{2} \omega_{r}{ }^{2}}}
\end{aligned}
$$

and

$$
B=\frac{2 \xi_{j}}{\omega_{g j}}
$$

These integrations are carried out using the complex plane and contour integration such that

$$
\begin{aligned}
& \overline{z_{i}{ }^{2}(x, t)}=\sum_{j=1}^{n} \sum_{r=1}^{m} \Phi_{i r}{ }^{2}(x) \frac{\Gamma_{r}{ }^{2} S_{j}}{\omega_{r}{ }^{4} M_{r}{ }^{2}} \pi \frac{A_{2} A_{3}-A_{1} A_{4}+A_{3} B^{2}}{A_{1}\left(A_{2} A_{3}-A_{1} A_{4}\right)-A_{3}{ }^{2}} \\
& \overline{\dot{z}_{i}{ }^{2}(x, \mathrm{t})}=\sum_{j=1}^{n} \sum_{r=1}^{m} \Phi_{i r}{ }^{2}(x) \frac{\Gamma_{r}{ }^{2} S_{j}}{\omega_{r}{ }^{4} M_{r}{ }^{2}} \pi \frac{A_{3}+A_{1} B^{2}}{A_{1}\left(A_{2} A_{3}-A_{1} A_{4}\right)-A_{3}{ }^{2}}
\end{aligned}
$$

The most interesting property of dynamic response is the mean square values of relative displacements at each floor level denoted by $\left\{z_{i}(x, t)-z_{i+1}(x, t)\right\}^{2}$.

Using the relations

$$
\begin{aligned}
& \overline{\left\{z_{i}(x, t)-z_{i+t}(x, t)\right\}^{2}}=\overline{z_{i}{ }^{2}} \overline{(x, t)}-\overline{2 z_{i}(x, t) z_{i+1}(x, t)+z_{i+1}{ }^{2}(x, t)} \\
& \left\{\overline{\left.\dot{z}_{i}(x, t)-\dot{z}_{i+1}(x, t)\right\}^{2}}=\overline{\dot{z}_{i}{ }^{2}(x, t)}-\overline{2 \dot{z}_{i}(x, t) \dot{z}_{i+1}(x, t)+\dot{z}_{i+1}(x, t)}\right.
\end{aligned}
$$

the mean square values of the relative displacements and their differential forms with respect to time $t$ are obtained as follows;

$$
\begin{aligned}
& \overline{\left\{z_{i}(x, t)-z_{i+1}(x, t)\right\}^{2}}=\sum_{j=1}^{n} \sum_{r=1}^{m}\left\{\Phi_{i, r}^{2}(x)-2 \Phi_{i, r}(x) \Phi_{i+1, r}(x)+\Phi_{i+1, r^{2}}(x)\right\} \\
& \cdot \frac{S_{j} \Gamma_{r}^{2}}{\omega_{r}{ }^{4} M_{r}{ }^{2}} \pi \frac{A_{2} A_{3}-A_{1} A_{4}+A_{3} B^{2}}{A_{1}\left(A_{2} A_{3}-A_{1} A_{4}\right)-A_{3}{ }^{2}} \\
& \overline{\left\{\dot{z}_{i}(x, t)-\dot{z}_{i+1}(x, t)\right\}^{2}}=\sum_{j=1}^{n} \sum_{r=1}^{m}\left\{\Phi_{i, r}{ }^{2}(x)-2 \Phi_{i, r}(x) \Phi_{i+1, r}(x)+\Phi_{i+1, r^{2}}(x)\right\} \\
& \cdot \frac{S_{i} \Gamma_{r}^{2}}{\omega_{r}{ }^{4} M_{r}{ }^{2}} \pi \frac{A_{3}+A_{1} B^{2}}{A_{1}\left(A_{2} A_{3}-A_{1} A_{4}\right)-A_{3}{ }^{2}}
\end{aligned}
$$




\section{NUMBER OF CYCLES IN RESPONSE DURING STRONG MOTION EXCITATION}

The probability density function for crossings of response $\alpha(t)$ at level $V$ with positive velocity is given by Roce's relation if the process is normal or Gaussian with zero mean value, i.e.,

$$
Q(V)=\frac{1}{2 \pi} \cdot \frac{\sigma_{\dot{\alpha}}}{\sigma_{\alpha}} \exp \left\{-\frac{1}{2} \frac{V^{2}}{\sigma_{\alpha}{ }^{2}}\right\}
$$

$\sigma_{\alpha}$ being the root mean square level of $\alpha$.

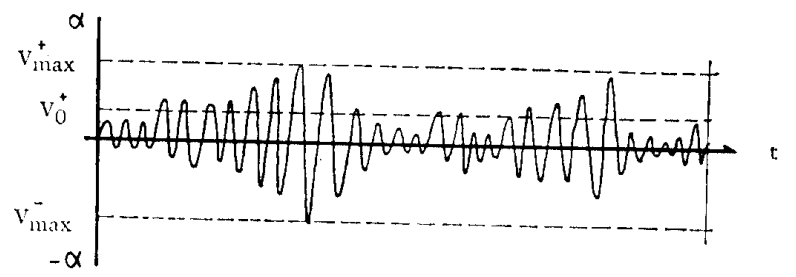

Fig. 4 Response of a narrow band System

The expected number of crossings of the level $V$ with positive slope during the time $T$ is, then, estimated as follows;

$$
N_{V}^{+}=\frac{T}{2 \pi} \frac{\sigma_{\dot{\alpha}}}{\sigma_{\alpha}} \exp \left(-\frac{V^{2}}{2 \sigma_{\alpha}^{2}}\right)
$$

where the time $T$ represents the duration of the strong earthquake excitation.

The most expected maximum response amplitude during the time $T$ is simply approximated by setting the number of crossings of the level $V^{+} \max$ equal to unity, i.e.,

$$
V_{\max }^{+}=\sqrt{2 \sigma_{\alpha}{ }^{2} \log \frac{T}{2 \pi} \frac{\sigma_{\dot{\alpha}}}{\sigma_{\alpha}}}
$$

\section{ACCELEROMETER RECORDINGS OF THE TOKACHI-OKI EARTHQUAKE}

Many strong motion accelerometer recordings were obtained during the Tokachi-Oki earthquake, of which two are shown in Fig. 5.

One was recorded on a SMAC-B 2, the station is situated at the port of Hachinohe and operated by the Port and Harber Research Institute. The instrument is placed on hollow concrete blocks $1.4 \mathrm{~m}$ by $1.4 \mathrm{~m}$ with a height of $0.5 \mathrm{~m}$. The blocks are on four $200 \mathrm{~mm}$ diameter piles. The soil is sand to a depth of about $10 \mathrm{~m}$, below this a clay layer extends for about $20 \mathrm{~m}$.

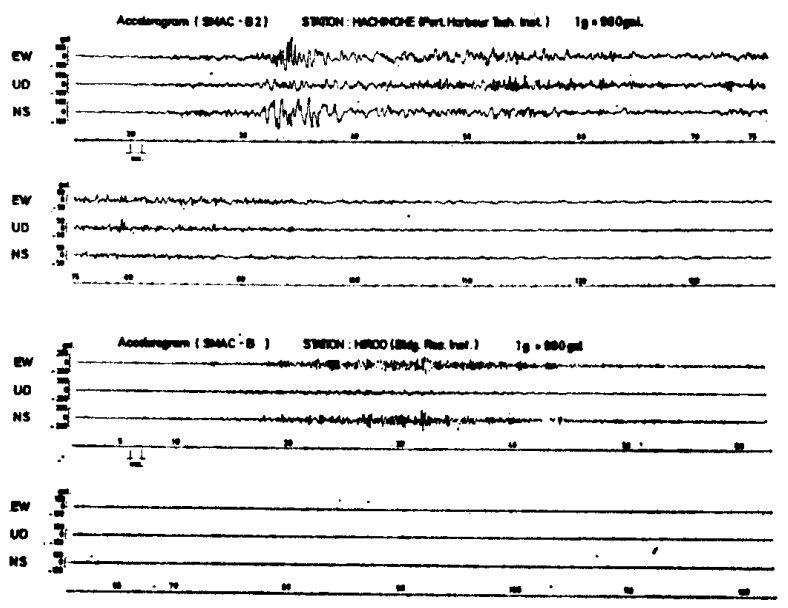

Fig. 5 Accelerometer recording Tokachi-Oki Earthquake

The recording at Hiroo was recorded on a SMAC-B, this station is operated by the Building Research Institute and located on a diluvium terrace which is covered by a layer of volcanic clay.

The foundation for the instrument is a $5.6 \mathrm{~m}$ by $5.6 \mathrm{~m}$ concrete block with a height of about $0.2 \mathrm{~m}$ and rests directly on the ground floor slab of a one-story wooden building. This concrete slab can be assumed to be structurely independent of the wooden building.

The autocorrelation and the power spectral density functions of the accelerometer recordings for 
the duration of the strong motion were computed, one of them is shown in Fig. 6, where a different unit of spectral density is used. The differences arise due to the use of cycles per unit time instead of radians per unit and also taking into account of only the posstive frequencies. The spectral density will be denoted by $W(f)$ where $f$ is frequency in cycles per unit time. The relation between $S(p)$ and $W(f)$ is simply

$$
W(f)=4 \pi S(p)
$$

Regarding that each power spectral density function can be the response of a single degree of freedom system represented by Eq. (2) when subjected to a white noise excitation $W_{\ddot{\imath}}(f)=W_{0}$, the function will be modified by applying the method of least squares as indicated by a broken line shown in Fig. 6.
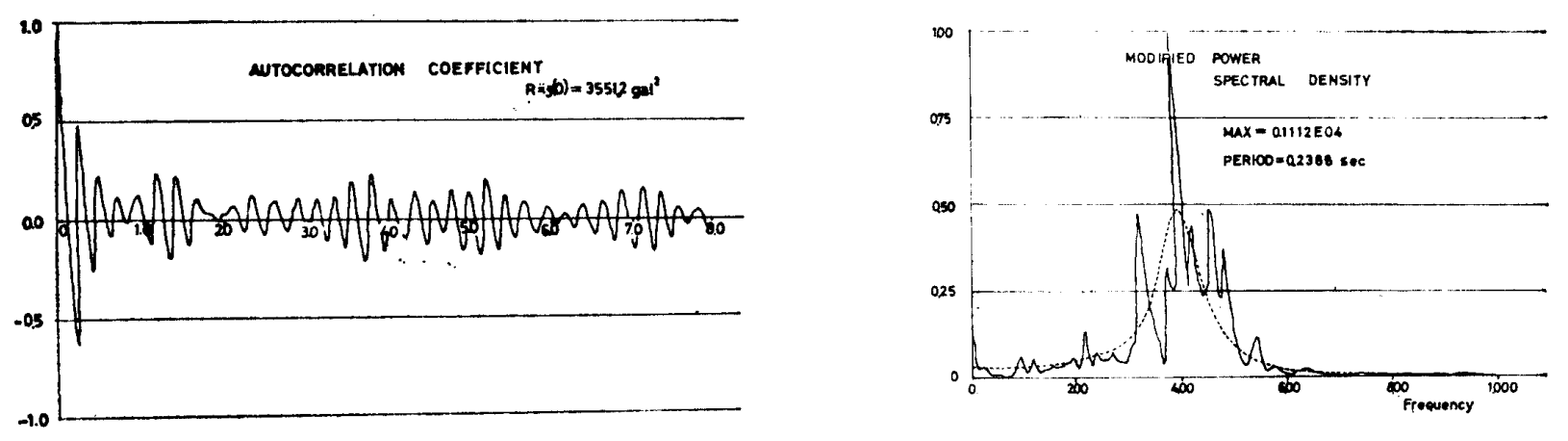

Fig. 6 Auto-Correlation and Power spectral Density functions (Hiroo EW)

The constant power spectral density function $S_{0}$, the ground damping foctor $\xi$ and the predominant ground frequency $\omega_{g}$ will be estimated from each modified function obtained by the method of least squares as shown in the following table.

Table 1

\begin{tabular}{|c|c|c|c|}
\hline & $\frac{\mathrm{cm}^{2}}{\mathrm{sec}^{4}} / \frac{\mathrm{rad}}{\mathrm{sec}}$ & $\xi_{j}$ & $\omega_{0 j} \frac{\mathrm{rad}}{\mathrm{sec}}$ \\
\hline HACHINOHE EW & $S_{0}=11.04608$ & $\xi=0.11714$ & $\omega_{g}=5.6862$ \\
\hline NS & $=13.404$ & $=0.17114$ & $=2.5234$ \\
\hline HIROO & $=10.44$ & $=0.1309$ & $=27.61$ \\
\hline NS & $=15.78$ & $=0.2559$ & $=25.06$ \\
\hline
\end{tabular}

\section{RESPONSE OF A REINFORCED CONCRETE BUILDING EXCITED BY THE TOKACHI- OKI EARTHQUAKE}

To clarify sections 3 and 4 the response of a three story building subjected to the Tokachi-Oki earthquake in the lateral direction as shown in Fig. 7 is presented as an example using the data of the Hiroo EW recording given in Table 1.

The mass and stiffness in the $y$ coordinates are

$$
\begin{array}{ll}
m_{1}=0.153 \text { ton }-\mathrm{sec}^{2} / \mathrm{cm} & k_{1}=326.80 \text { ton } / \mathrm{cm} \\
m_{2}=0.252 \quad \text { " } & k_{2}=325.80 " ~ \\
m_{3}=0.255 \quad k_{3}=386.70 " ~
\end{array}
$$

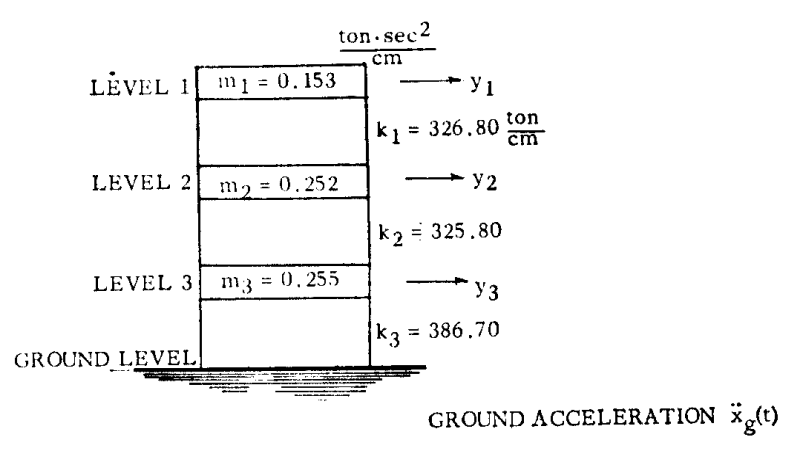

Fig. 7 Model 
The normal modes and natural frequencies of the building are given by

$$
\begin{aligned}
& \left\{\Phi^{(1)}\right\}=\left\{\begin{array}{r}
1.0000 \\
0.8323 \\
0.4367
\end{array}\right\} \quad \omega_{1}=18.87 \mathrm{rad} / \mathrm{sec} \\
& \left\{\Phi^{(2)}\right\}=\left\{\begin{array}{r}
1.0000 \\
-0.1936 \\
-1.0090
\end{array}\right\} \quad \omega_{2}=50.49 \mathrm{rad} / \mathrm{sec} \\
& \left\{\mathscr{D}^{(3)}\right\}=\left\{\begin{array}{r}
1.0000 \\
-1.1610 \\
0.8157
\end{array}\right\} \quad \omega_{3}=67.94 \mathrm{rad} / \mathrm{sec}
\end{aligned}
$$

The property of the ground layer under the building and the constant power spectral obtained from the Hiroo EW accelerometer recording are repeated here convenience.

$$
\begin{aligned}
S_{0} & =10.44 \frac{\mathrm{cm}^{1}}{\mathrm{sec}^{4}} / \frac{\mathrm{rad}}{\mathrm{sec}} \\
\omega_{g} & =27.61 \mathrm{rad} / \mathrm{sec} \\
\xi & =0.1309
\end{aligned}
$$

Using Eqs. (21), (22), (25) and (26), the mean square values of $z_{i}$ and $\dot{z}_{i}$ and the mean square values of $z_{i}-z_{i+1}$ at the floor levels in the building are computed.

Regarding that the duration of the strong earthquake excitation was $t=28.0 \mathrm{sec}$, the expected maximum displacements relative to the base and the expected maximum story displacements at the floor levels are obtained from Eq. (29) and the above mean square values.

These results are compared with the corresponding values computed by a deterministic analysis method as shown in Table 2 .

Table 2

\begin{tabular}{cc|c|c}
\hline & & Non-deterministic & Deterministic \\
\hline Max. displacement relative to base $\mathrm{D}_{1}$ & $1.541 \mathrm{~cm}$ & $1.2202 \mathrm{~cm}$ \\
& $\mathrm{D}_{2}$ & $1.283 \mathrm{~cm}$ & $1.0188 \mathrm{~cm}$ \\
" & $\mathrm{D}_{3}$ & $0.674 \mathrm{~cm}$ & $0.5429 \mathrm{~cm}$ \\
Maximum story displacement & $\mathrm{d}_{1}$ & $0.264 \mathrm{~cm}$ & $0.2456 \mathrm{~cm}$ \\
& $\mathrm{~d}_{2}$ & $0.612 \mathrm{~cm}$ & $0.5225 \mathrm{~cm}$ \\
& $\mathrm{~d}_{3}$ & $0.674 \mathrm{~cm}$ & $0.5429 \mathrm{~cm}$ \\
\hline
\end{tabular}

The expected number of cycles with the varying intensities of the repeated story shearing forces at the floor levels can be estimated for the duration of the strong motion from Eq. (23) and the mean square values as shown in Table 3.

Table 3

\begin{tabular}{c|c|c|c|c|c|c}
\hline & \multicolumn{2}{|c|}{$3 \mathrm{rd}$ story } & \multicolumn{2}{|c|}{2 nd story } & \multicolumn{2}{|c}{1 st story } \\
\hline $\begin{array}{c}\text { Max. story } \\
\text { shear P max. }\end{array}$ & $86.1 \mathrm{t}$ & $\begin{array}{c}\text { cycles } \\
1.0\end{array}$ & $199.4 \mathrm{t}$ & $\begin{array}{c}\text { cycles } \\
1.0\end{array}$ & $260.6 \mathrm{t}$ & $\begin{array}{c}\text { cycles } \\
1.0\end{array}$ \\
\hline $0.9 \mathrm{P}$ & 77.5 & 2.36 & 179.5 & 2.35 & 234.5 & 2.35 \\
$0.8 \mathrm{P}$ & 68.9 & 5.11 & 159.5 & 5.03 & 208.5 & 5.03 \\
$0.7 \mathrm{P}$ & 60.3 & 10.1 & 139.6 & 9.86 & 182.4 & 9.86 \\
$0.6 \mathrm{P}$ & 51.7 & 18.2 & 114.6 & 17.7 & 156.4 & 17.7 \\
$0.5 \mathrm{P}$ & 43.1 & 29.9 & 99.7 & 28.9 & 130.3 & 29.0 \\
$0.4 \mathrm{P}$ & 34.4 & 44.9 & 79.8 & 43.4 & 104.2 & 43.4 \\
$0.3 \mathrm{P}$ & 25.8 & 61.7 & 59.8 & 59.3 & 78.2 & 59.4 \\
$0.2 \mathrm{P}$ & 17.2 & 77.4 & 39.9 & 74.3 & 52.1 & 74.3 \\
$0.1 \mathrm{P}$ & 8.6 & 88.7 & 19.9 & 85.0 & 26.1 & 85.0 \\
$0.0 \mathrm{P}$ & 0.0 & 92.8 & 0.0 & 88.9 & 0.0 & 88.9 \\
\hline
\end{tabular}

\section{DISCUSSION}

It is clear from the above analysis that the response of a building due to $a$ future strong earthquake excitation is predictable if the bedrock power spectral density $S_{0}$ and the property of the layer $\omega_{g}$ and $\xi$ can be evaluated at the building site.

Moreover, to design a building with safety for life and property in mind, the expected maximum power spectral density $S_{0}$ max. should be estimated, which seems to be closely related to the property 
of the layer under the building.

For this reason, the autocorrelations $R_{\ddot{x} \theta}(0)$ of ground accelerations $\ddot{x}_{\theta}$ are calculated from many past earthquake recordings and the mean value and the varience are

$$
\begin{aligned}
& \overline{R_{\ddot{x}_{g}}(0)}=3,470.93 \mathrm{gal}^{2} \\
& \sigma_{R_{\ddot{x}_{\theta}}}{ }^{2}(0)=1.4293 \times 10^{6} \mathrm{gal}^{4}
\end{aligned}
$$

The possibile maximum $R_{\ddot{x} g}(0)$ may be taken as the design level of $3 \sigma_{R_{\ddot{x}}}{ }^{2}(0)$ from an engineering point of view, although a precise conclusion cannot be drawn due to insufficient number of data of Table 4.

$$
R_{\ddot{x} g}(0) \max =\overline{R_{\ddot{x} g}(0)}+3 \sigma R_{\ddot{x}_{g}}(0)=7,057.49 \mathrm{gal}^{2}
$$

Therefore, the possible maximum power spectral density $S_{0 \text { max }}$, is derived from Eq. (5) as follows;

$$
S_{0 \max }=\frac{R_{\ddot{x}_{\theta}}(0)_{\max }}{\pi \omega_{g}\left(2 \xi+\frac{1}{2 \xi}\right)} \doteqdot \frac{7,000.0}{\pi \omega_{g}\left(2 \xi+\frac{1}{2 \xi}\right)}
$$

\begin{tabular}{|c|c|c|c|c|c|c|}
\hline \multirow[b]{2}{*}{ Vernon, Calif. Oct. 2, 1933} & \multicolumn{6}{|c|}{$R_{\ddot{x}_{0}}(0)$ and $T$} \\
\hline & NO $8 \mathrm{E}$ & $4,660.5 \mathrm{gal}^{2}$ & $0-9$ sec & S $82 \mathrm{E}$ & $4,102.8 \mathrm{gal}^{2}$ & $0-9 \mathrm{sec}$ \\
\hline Los Angeles Subway Terminal Oct. 2, 1933 & $\mathrm{~N} 39 \mathrm{E}$ & $3,416.8$ & $0-9 "$ & $\mathrm{~N} 51 \mathrm{~W}$ & $3,088.4$ & $0-9$ " \\
\hline El Centro, Calif. May 18,1940 & NS & $4,213.7$ & $0-29 "$ & $\mathrm{EW}$ & $6,023.9$ & $0-29 "$ \\
\hline Santa Barbara, Calif. June 30, 1941 & $\mathrm{~N} 45 \mathrm{E}$ & - & & $\mathrm{S} 45 \mathrm{E}$ & $2,907.3 "$ & $0-10 "$ \\
\hline Hiroo May 16, 1968 & NS & $2,626.4 ”$ & $0-28$ " & $\mathrm{EW}$ & $3,551.2 ”$ & $0-28 ”$ \\
\hline Hachinohe May, 16, 1968 & NS & $1,703.8$ & $0-34 "$ & $\mathrm{EW}$ & $1,875.4 ”$ & $0-34$, \\
\hline
\end{tabular}

Table 4

The predominant frequency $\omega_{g}$ and the damping factor $\xi$ should also be measured with accuracy before the construction commerces.

It has been suggested that these values can be approximated from microtremor measurements or artificial earthquake methods.

However, the considerable techniques and modification will be required to evaluate these values with acctracy because of the extremely different characteristics of these excitations.

Furthermore, from the experimental data in the past it is observed that the accelerometer recordings measured at the base of a building during an excitation are more or less different from those recorded on the surface of the ground depending on the ground condition at the building site.

These involve many problems to be solved and are the subjects for future researches.

\section{ACKNOWLEDGEMENT}

The authors wish to thank Dr. Joseph Penzien, Professor of the University of California, Berkeley for suggesting this problem and for stimulating interest in it.

\section{REFERENCES}

1) Clough and Penzien: "Structural Dynamics", McGraw-Hill Book Company, Inc., New York, Toront, London.

2) Crandall and Mark : "Random Vibration", Academic Press, New York and London, 1963.

3) Robson : "Random Vibration", Edinburgh University Press, Elservier Publishing Company, 1964.

4) Davenport and Root: "Random Signals and Noise", McGraw-Hill Book Company, Inc., New York, Toronto, London, 1958.

5) Hurty and Rubinstein : "Dynamics of Structures", Prentice-Hall, Inc. Englewood Cliffs, New Jersey, 1964.

6) Hiroshi Tajima: "A Statistical Method of Determining the Maximum Response of a Building Structure during an Earthquake", Proceedings of the Second World Conference on Earthquake Engineering, Vol. II, Gakujutsu Bunken Fukyu-Kai, Tokyo, 1960.

7) Kanai, Kobori and Hiruta : "Seismology and structural Dynamics", Systematic Series of Architecture, Vol. 11, Shōkoku-sha, Tokyo, Japan, 1963.

8) N.N. Nielsen and K. Nakagawa : "The Tokachi-Oki Earthquake, Japan, May 16, 1968, a Preliminary Report on the Damage to Structures", IISEE Earthquake Report No. 2, 1968. 


\section{$\mathbf{R C}$ 構造物の地震応答予 測 $^{1)}$ (梗 概)}

\section{1. 緒言}

本研究の目的注, 構造物の地震動汹対する動的応答を 予測する場合の（即ち，動的設計に通ずる）確摔論的解 析方法を確立することである。

従来の地震動に対する動的応答計算は，実際に得られ た地震記録を入力とし， step-by-step で行う。この方法 で構造物の動的設計を行う場合に問題となるのは，構造 物のモデル化にあるのは勿論であるが，入力地震波の選 択にある。入力地震波としてどの波を採用するか，ある いは最大加速度をいくらにするかで応答值はいくらでも 変わってしまう。将来の設計をするに当り，過去の特定 の地震波を採用するのは如何にも不合理である。この点 から，実際問題として数種の地震波を用いて，平均的な あるいは包絡線的な考え方で設計をしているわけである が，それでもなお採用した地震波群が，将来起り得る地 震波のパターンを網羅しているかどらかという点で不安 が残るわけである。構造物が建てられる地盤上で，将来 どのような地震動が記録されるかは不明である（波形に 関して）。従来行われている step-by-step の応答計算は， 動的解析には久かせぬものであるが，構造物の動的設計 には上記の理由から不適当と考えられる。

本研究では構造物の動的設計におけるこのような久点 を除いて，まず地震波は波形を問題とせず，その特性の みを用いて応答予測を行なおうとするものである。ある 地域で記録される地震波の特性は, 地震自体の特性, そ の地城の地盤の特性, 震央距離等によって統計的, 確率 的に予測しらるものと考えられる。本研究はここれらの 特性が何らかの方法によって定められた時に，これらを 入力として与える事によって，ある地域化建てられる構 造物の予想応答值を求めようとするものである。これか ら得られる応答值注, 統計的, 確率的に得られるもので あるから，従来の応答計算法による動的設計時に考えら れる危険性は除かれるわけである。

1）昭和 44 年 8 月北海道大会で発表したものである。

$* 1$ 建設省建築研究所 研究員 $* 2$ 同.工博 (昭和 44 年 9 月 30 日本稿受理・卻諭期限昭和 45 年 8 月末日)

$\begin{array}{ccccc}\text { 正会員 } & \text { 尾 } & \text { 崎 } & \text { 昌 } & \text { 凡*2 } \\ " & \text { 渡 } & \text { 部 } & & \text { 丹*2 } \\ " & \text { 広 } & \text { 沢 } & \text { 雅 } & \text { 也*1 } \\ \text { " } & \text { 松 } & \text { 島 } & & \text { 豊*2 } \\ \text { " } & \text { 山 } & \text { 崎 } & & \text { 裕*1 }\end{array}$

本論文は, 最初に理論を述べた後, '68 年十勝沖地震 時に得られた北海道広尾 $\mathrm{SMAC}$ 記録から,この地震波 の特性を抽出し，これを入力として，同地震時に被害を うけたR C 構造物の応答を予測し, 従来法による応答值 との比較を行なって，本理論の例題としてある。

\section{2. 解析理論}

地震力が構造物に入り, 破壊を生ぜしめるまでの伝播 経路をChart 1 に示す。今，ある地震に対して地震基盤 においてパワースペクトル密度が，一定值 $S_{0}$ であると する。この場合の地盤面の自己相関関数とパワースペク トル密度関数は, 金井, 多治見雨博士により, 式 (1), 式 (2) で与えられる。式 (2) は $P=\omega_{g}$ で一つのピー クを有する関数であるが，今いくつかのピークを有する 場合に適用するために式 (3), 式 (4) を考えることとす る。

つぎにこれらの特性を有する地盤面上の構造物を考え る。構造物の塑性域を考えない場合には，式 (6) 以下式 （11）までのように各次のモードに分解して計算するこ とができる。その際の解は式 (12) で与えられる。この 解およびこの解の 1 階微分の自己相関をとると，それぞ れ式 (13)，式 (14) となる。両式中で $\tau \rightarrow 0$ とすれば 応答の二乗平均值を与えることになる。これが式 (15)， 式（16）である。これらを整理したのが式（21）および 式 (22) である。これが構造物基礎に対する絶対変位お よび速度の二乗平均值である。層間変位および速度の二 乗平均值は式 (25), 式 (24) を用いて, 式 (25), 式 (26) で示される。

つぎに応答波形の一定レベルに対する繰り返し回数を 計算してみる。応答波形を $\alpha(t)$ として $\alpha(t)$ がレベル $V$ を正の傾きで切る確率密度関数は， $\alpha(t)$ の平均值が 零で，かつ正規分布しているならば式 (28) で与えられ る。また，この式を用いて $\alpha(t)$ の最大值レベルを計算

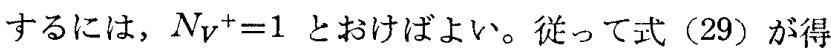
られるわけである。本文第 3 項までで， $\sigma_{\alpha}, \sigma_{\alpha}$ に対する ものが計算されているから，式（29）を用いることによ って応答の最大值を予測することができる。 


\section{3. 計 算 例}

本理論の計算例として, 1968 年の十勝沖地震をとりあ げてみる。入力としては北海道広尾の SMAC 記録を利 用して, 通常の応答計算值と比較してみる。構造物は同 地地震時に被害を受けた 3 層 $\mathrm{R} \mathrm{C}$ 造を用いる。

Fig. 5 の広尾 $\mathrm{EW}$ の記録の自己相関関数, パワース ペクトル密度関数を計算すると Fig. 6 のようになる。 Fig. 6 右図中の点線のカーブは実線が式 (2) の関係に あるものとして, 最小二乗法により求めたものである。

Table 1 にはこうして得られた地震波の特性を示すファ クター, $S_{0}, \xi, \omega_{g}$ の値を示してある。広尾 $\mathrm{EW}$ に対す る計算結果を Table 2 に示寸。左欄が本法による結果, 右欄が通常の忘答計算結果である。Table 3 には構造物 各層における剪断力の繰り返し回数を計算してある。

\section{4. 検 討}

以上の解析から明らかなように, 構造物の所在する場 所での基盤のパワースペクトル密度 $S_{0}$ と, 地盤の特性 $\xi, \omega_{g}$ が知られれば，将来起り得る強震に対する構造物 の応答を予測できる。したがって $S_{0}, \xi, \omega_{g}$ を定めるこ とが重要となるわけであるが, このうち $\xi, \omega_{g}$ は常時微 動, 人工地震等によって, ある程度近似值が得られる。 今 Table 4 亿示される地震の自己相関関数 $(\tau=0)$ の 值の平均值 $\overline{R_{\ddot{x}_{g}}(0)}$, 掠よび分散 $\sigma_{R} \ddot{x}_{g}(0)$ を用いると $R_{\ddot{x}_{y}}(0)$ の最大值は式（31）で表わされよう。さらに式 (5a) を用いると式 (32) の関係が導かれる。したがっ て $\xi, \omega_{g}$ が何等かの方法で決まれば $S_{0}$ の予想最大值 $S_{0 \text { max }}$ 計算することができるわけである。

式 (31) の数値はあくまで Table 4 の地震からのみ 計算したものである。実際にはより広範なデータを用い ての分類的処理も必要になろう。

最後に, この問題を提起し, かつそれに対する興味を 换起して下さったカリフォルニア大学バークレイ教授, ジョセフ・ペンゼン博士に深く感謝の意を表したい。 


\section{TRANSACTIONS OF THE ARCHITECTURAL INSTITUTE OF JAPAN}

\section{S Y N O P S I S}

U.D.C.691.87:691.32

\section{REINFORCED CONCRETE WITH BUNDLED BAR}

(See Page 11)

By TATSUHIKo SAITO, Chief Structural Engineer, Engineering Department of Taisei Construction, Co. I td. and HIDEO TSUCHIYA. Structural Engineer, Engineering Department of Taisei Construction, Co, Ltd., Members of A.I.J.

The arc welded joints of high strength deformed bars have been studied. Butt, lap, and splice joints were used. The ultimate strength of high strength deformed bars varied from 60,000 psi to 80,000 psi. Ordinary manual arc welding and enclosed are welding were used. The results are obtained as follows : (a) the bend test about the short beaded is the most convenient method to determine the weldalility of the bars; (b) suitable preheating is needed to obtain good welded joints.

U.D.C. $550: 34: 624.012 .4$

\section{EARTHQUAKE RESPONSE PREDICTION OF REINFORCED CONCRETE BUILDING}

(See Page 21)

By MASAHIRO OZAKI, Research Member of Building Research Institute, Ministry of Construction, HIROSHI WATABE, and others, Research Member of Building Research Institute, Ministry of Construction. Members of A.I.J.

By Dr. TOSHIRo SUZUKI, Assist. Prof. Nagoya Institute of Technology and TETSURO ONO, Graduate Student Nagoya Institate of Technology. Members of A.I.J.

In the previous paper, writers have reported about the post buckling behaivior of the inelastic steel beams 